
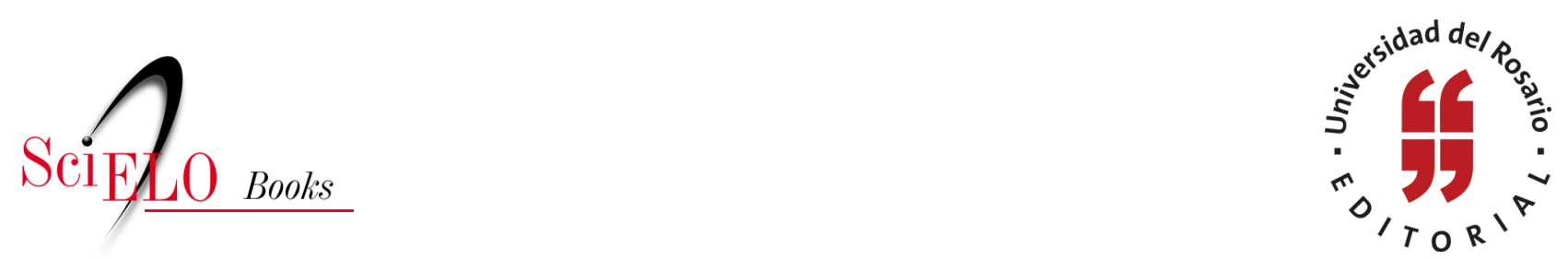

\title{
Siglas y abreviaturas
}

\author{
Joel M. F. Ramírez-Mendoza
}

RAMÍREZ MENDONZA, J.M.F. Siglas y abreviaturas. In: Diferencias entre las reglas de exclusión probatoria colombiana e internacional penal. Análisis en tres casos de injerencias en comunicaciones privadas [online]. Bogotá: Editorial Universidad del Rosario, 2015, pp. 15-16. Opera prima collection. ISBN: 978-958-738-658-5. https://doi.org/10.7476/9789587386585.

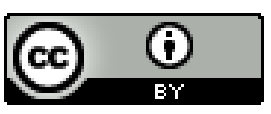

All the contents of this work, except where otherwise noted, is licensed under a Creative Commons Attribution 4.0 International license.

Todo o conteúdo deste trabalho, exceto quando houver ressalva, é publicado sob a licença Creative Commons Atribição 4.0.

Todo el contenido de esta obra, excepto donde se indique lo contrario, está bajo licencia de la licencia $\underline{\text { Creative }}$ Commons Reconocimento 4.0 . 


\section{Siglas y abreviaturas}

art. / arts. Artículo/artículos

A. BiH Ejército de Bosnia-Herzegovina

AUC Autodefensas Unidas de Colombia

DutchBat Batallón Holandés

CADH Convención Americana de Derechos Humanos

$\mathrm{CIDH}$ Corte Interamericana de Derechos Humanos

CEDH Corte Europea de Derechos Humanos

CPI Corte Penal Internacional

CP Código Penal

CPP Código de Procedimiento Penal

CTI Cuerpo Técnico de Investigación

DIDH Derecho Internacional de los Derechos Humanos

DIH Derecho Internacional Humanitario

ER Estatuto de Roma

FARC Fuerzas Armadas Revolucionarias de Colombia

inc. Inciso

Lit. Literal

Mup Policía de República de Sprska

n. Nota al pie de página

num. Numeral

PIDCP Pacto Internacional de Derechos Civiles y Políticos

RGT Reglamento concerniente a las leyes o costumbres de la Guerra Terrestre 


$\begin{array}{ll}\text { RIME } & \text { Regional de Inteligencia Militar del Ejército } \\ \text { RPP } & \text { Regla(s) de Procedimiento y Prueba } \\ \text { RS } & \text { República de Sprska } \\ \text { SIPOL } & \text { Seccional de Inteligencia Policial } \\ \text { TPIY } & \text { Tribunal Penal Internacional para la ex-Yugoslavia } \\ \text { TPIR } & \text { Tribunal Penal Internacional para Ruanda } \\ \text { UNHCR } & \text { Naciones Unidas para los Refugiados } \\ \text { UNPROFOR } & \text { Fuerzas de Protección de las Naciones Unidas } \\ \text { VRS } & \text { Ejército de la República de Sprska }\end{array}$

